INTERNATIONAL MONETARY FUND

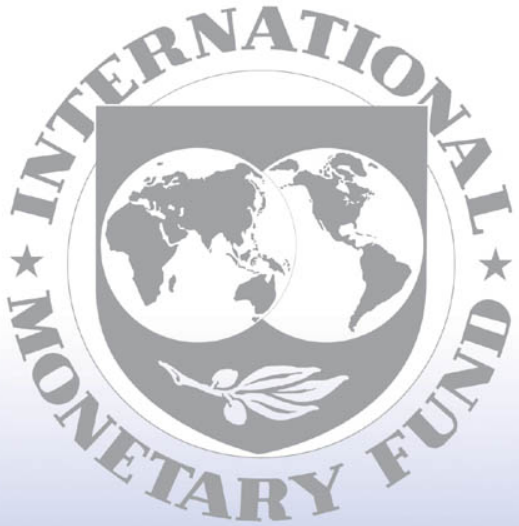

Staff

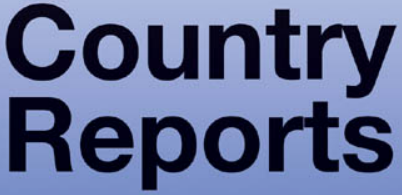




\section{Turkey: Report on the Observance of Standards and Codes- Fiscal Transparency Module}

This Report on the Observance of Standards and Codes on Fiscal Transparency for Turkey was prepared by a staff team of the International Monetary Fund as background documentation for the periodic consultation with the member country. It is based on the information available at the time it was completed on March 9, 2006. The views expressed in this document are those of the staff team and do not necessarily reflect the views of the government of Turkey or the Executive Board of the IMF.

The policy of publication of staff reports and other documents by the IMF allows for the deletion of market-sensitive information.

To assist the IMF in evaluating the publication policy, reader comments are invited and may be sent by e-mail to publicationpolicy@imf.org.

Copies of this report are available to the public from

International Monetary Fund $\bullet$ Publication Services

700 19th Street, N.W. • Washington, D.C. 20431

Telephone: (202) 6237430 • Telefax: (202) 6237201

E-mail: publications@imf.org • Internet: http://www.imf.org

Price: $\$ 15.00$ a copy

\section{International Monetary Fund Washington, D.C.}


This page intentionally left blank

(C)International Monetary Fund. Not for Redistribution 
INTERNATIONAL MONETARY FUND

\title{
TURKEY
}

\section{Report on the Observance of Standards and Codes (ROSC) Fiscal Transparency Module}

\author{
Prepared by the Fiscal Affairs Department
}

Approved by Michael Deppler and Teresa Ter-Minassian

March 9, 2006

\section{EXECUTIVE SUMMARY}

At the authorities' request, the IMF has conducted an assessment of practices in Turkey in relation to the requirements of the IMF Code of Good Practices on Fiscal Transparency. The present report provides this assessment, based on discussions with the authorities, other organizations, the authorities' response to the IMF fiscal transparency questionnaire and other information. The IMF Manual on Fiscal Transparency (http://www.imf.org/external/np/fad/trans/manual) discusses terms and concepts used in this report.

This assessment comes at a critical juncture, as the economic situation in Turkey has improved substantially since the 2000-01 crisis, which is a time to cement achievements and move the agenda forward, and as Turkey begins to prepare for its most important economic negotiation ever. Addressing the transparency shortcomings identified in the 2000 ROSC fiscal transparency module has been an integral part of the ambitious program of economic and structural reforms adopted by the Turkish authorities in response to the crisis. Those shortcomings included: inadequate budget coverage and framework for managing contingent liabilities; fragmentation of budget responsibilities across various institutions; and the absence of a medium-term framework to guide the annual budget exercise. The ROSC update undertaken in 2002 noted that progress has been made, including through the adoption of the 2002 Law on Public Finance and Debt Management (PFDML), which created a comprehensive and more transparent risk management framework; the closing of hundreds of "revolving funds;" and the reduction in the number of extrabudgetary funds. However, the 2002 ROSC update also pointed to a number of pervasive weaknesses in the system, including quasi-fiscal activities (QFA) and the absence of an appropriate fiscal management framework law to underpin the implementation of further reforms.

Since the 2002 update, Turkey has continued to make progress toward meeting the requirements of the fiscal transparency code, in particular through a substantial overhaul of the legal system. The adoption, in December 2003, of the Public Financial Management and Control Law (PFMCL) was designed to provide the necessary framework for further reforms. Its implementation is scheduled for completion in 2006.

In spite of the progress made, further effort is required before Turkey will fully meet the requirements of the Code. Implementation of reforms can be hampered by uncertainty in the legislative environment. For example, numerous amendments to the PFMCL and other laws are now with Parliament, and the absence of hierarchy in Turkey's legal system exacerbates this uncertainty.

Further progress will hinge on the authorities' ability to continue to implement the new Budget legislative framework. The authorities should pay close attention to two major aspects of the reform program in this area:

- in their current versions, these laws, which are designed to provide a broad legal framework for reforms, do not fully address the issue of fragmentation, nor other critical aspects of fiscal management;

- achieving implementation in the proposed timeframe will be a challenge, requiring a strong build-up in the level of ownership at all levels of government, as well as a major effort in preparing the key actors for their new role.

Against the backdrop of a substantially strengthened fiscal position, a more sustainable debt position, and positive steps towards EU accession, the ROSC provides a set of recommendations in the key areas of reform to assist the authorities in meeting the challenges described above. 


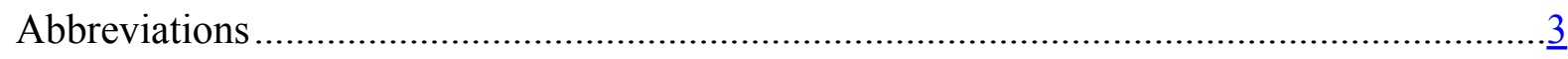

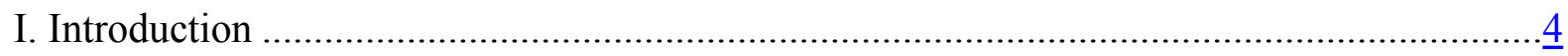

II. Detailed Description of Practice ………………............................................................ 4

A. Clarity of Roles and Responsibilities..................................................................

B. Open Budget Preparation, Execution, and Reporting ………………………......17

C. Public Availability of Information ................................................................

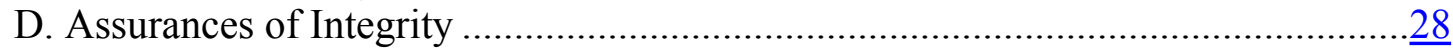

III. IMF Staff Commentary ............................................................................................

A. Measures to Improve the New Budget Legislative Framework ……………….....

B. Measures to Facilitate the Implementation of the

New Budget Legislative Framework ……………………................................

C. Measures to Enhance the Transparency of the Tax System:....................................37

D. Other Measures …………………………………............................................

IV. Recommendations Relating to Fiscal Decentralization..................................................

Tables

1. Government Ownership of Nonfinancial Corporations 2005 .............................................

2. Structure of Local Governments' Consolidated Accounts 2004 (preliminary) .....................11

3. Turkey - Budget Projections and Realizations .................................................................

Boxes

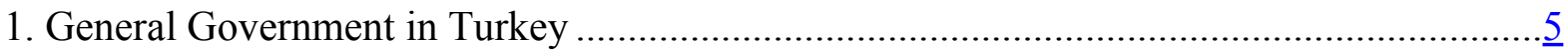

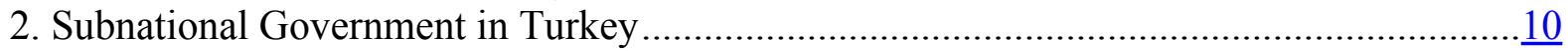

3. Proposed Reforms to the Turkish Budget Process.............................................................

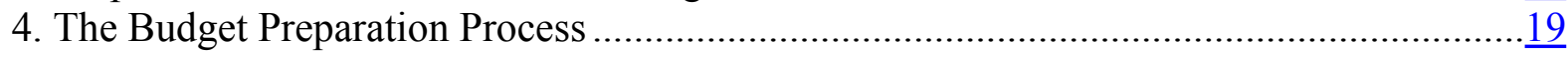




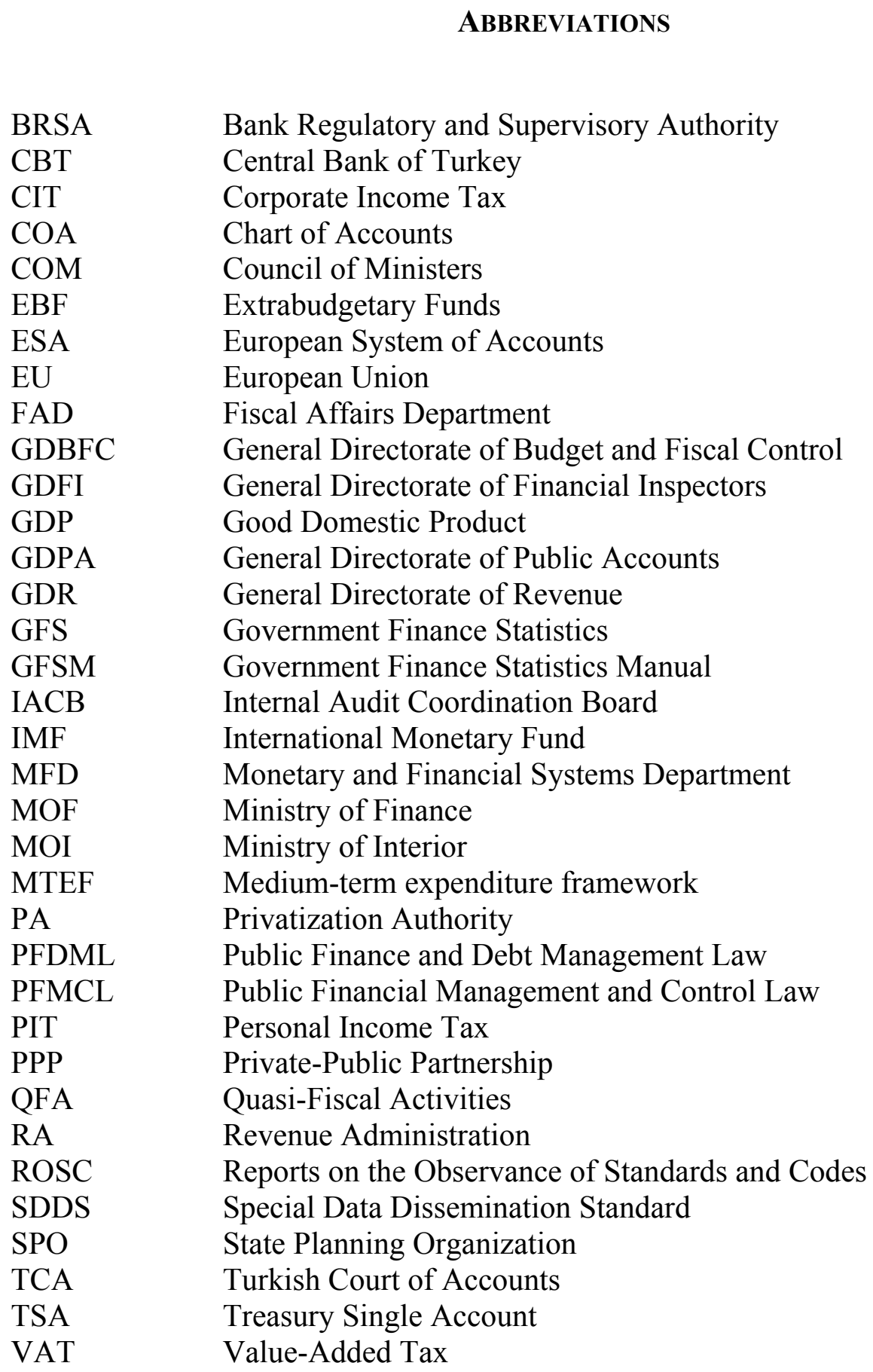




\section{INTRODUCTION ${ }^{1}$}

1. This draft report provides an assessment of fiscal transparency practices in Turkey against the requirements of the IMF Code of Good Practices on Fiscal Transparency. The assessment has two parts. The first part is a description of practice, prepared by the IMF staff on the basis of discussions with the authorities and their responses to the fiscal transparency questionnaire, and drawing on other available information. The second part is an IMF staff commentary on fiscal transparency in Turkey.

\section{Detailed Description of Practice}

\section{A. Clarity of Roles and Responsibilities}

\section{Definition of government activities}

\section{General government is broadly defined in accordance with Government Finance} Statistics (GFS) principles. The units of general government are listed in Box 1. There are, however, several problems relative to GFS definitions. The general government sector according to the new Public Financial Management and Control Law (PFMCL) includes some commercial activities undertaken by certain revolving funds (the authorities have not yet performed a full assessment of their activities). ${ }^{2}$ On the other hand, the definition excludes foundations set up by line ministries. ${ }^{3}$ It also excludes the Iller Bank which, while nominally an investment Bank, operates under the Ministry of Public Works and has many characteristics of an extrabudgetary fund (it provides financial and other services to municipalities, and invests in municipal infrastructure). The definition of general government employed in the Central Bank of Turkey's (CBT) monetary survey is slightly different: it includes ministerial foundations, but excludes the savings and deposit insurance fund. It, too, excludes Iller Bank.

\section{The government owns significant shareholdings in a number of corporations, which} are governed by appointed Boards. The 39 state economic enterprises in the government's portfolio (Table 1) are expected to produce earnings (before interest, taxes, depreciation, amortization, and other provisions) of about 2 percent of Gross Domestic

\footnotetext{
${ }^{1}$ Discussions on fiscal transparency were held in Ankara during May 20-June 3, 2005. The Fiscal Affairs Department (FAD) mission team, comprising Messrs. Jesús Seade (Head), Luc Leruth, Brian Olden, Mark Flanagan (all FAD) and Paul Bernd Spahn (IMF panel expert), was supported by the IMF resident representative office in Turkey. The staff team met with officials from the Treasury, Ministry of Finance, Ministry of Interior, State Planning Organization, Ankara Municipality, some members of Parliament; Budget and Finance Committee, and independent observers.

${ }^{2}$ Revolving funds are extrabudgetary accounts of line ministries and other budget and annexed agencies which collect revenues in return for services.

${ }^{3}$ Foundations solicit public donations (often at the time the service is provided). Resources are used to supplement line ministry activities (for instance, by purchasing vehicles).
} 


\section{Box 1. General Government in Turkey}

I. General government in Turkey comprises the following at present :

Expenditures

(2004, in percent of GDP)

\section{Central Government Units Covered by the Budget}

1. General Public Services, including parliament, president's office, judiciary,

2. Special budget agencies, including universities (102 in total)

n.a.

\section{Central Government Units with Individual Budgets}

3. EBFs (5), including the Defense Industry Support Fund, the Social Solidarity and Aid Fund, the Privatization Authority, the Promotions Fund and the Savings and Deposit Insurance Fund.

4. Social security institutions (5), including SSK (workers), Bag-Kur (self-employed and agriculture), Emekli-Sandiği (civil servants), Is-Kur (unemployed), and Amele

Birligi (coal workers fund)

5. Regulatory boards $(10)$

6. Revolving funds $(1,434)$

7. Ministerial foundations (n.a.)

\section{Local Government}

8. Special Provincial Administrations (81) 0.4

9. Metropolitan municipalities (16) 1.3

10. Other municipalities $(3,212) \quad 2.2$

11. EBFs (the Iller Bank) (1) n.a.

12. Semi-autonomous bodies under metropolitan municipalities (gas, water and sewer n.a. administrations)

II. When the PFMCL is fully implemented, the central government budget will be expanded to include:

3. EBFs

5. Regulatory boards

6. Revolving funds

1.6

Source: State Planning Organization

Product (GDP) in 2005. Several of these enterprises are listed companies with minority private holdings, and are thus subject to more stringent audit and reporting requirements. The government also fully owns three large state banks, which account for 36 percent of banking system assets, and 41 percent of deposits. Since 2000, State Banks have been subjected to commercial and banking law. The Bank Regulatory and Supervisory Authority (BRSA) is responsible for regulating them, and Treasury, as their principal shareholder, appoints their Boards. The Treasury is also ultimately responsible for overseeing and monitoring the operations of state economic enterprises (the privatization authority also monitors enterprises assigned to it). Monitoring is on a monthly basis (for financing data) and semi-annual basis (for operational data). State enterprises have outside auditors, and are also subject to audit by Treasury's auditors. Decree Law 233 sets out the norms for state enterprise governance, and for each company establishes a quota of 
Directors to the enterprise's Board to be appointed by the Treasury and by the related line ministry.

\section{The government exercises a significant influence on how state enterprises are run.}

State enterprises are subject to strong government direction to meet targets for financial performance. Treasury regularly issues directives to improve state enterprise operations (e.g., to raise prices, cut employment, limit administrative expenses), and it approves all of their external borrowing with the exception of short-term external borrowing of public investment and development banks. The State Planning Organization (SPO) approves their investment program. The Prime Ministry negotiates wages with the public workers' union across all enterprises. The transfer of dividends from state enterprises to the budget are determined on a discretionary basis after establishing a state enterprises' annual operating

Table 1. Government Ownership of Nonfinancial Corporations 2005

\begin{tabular}{|c|c|c|}
\hline State Enterprise & Activity & State Share \\
\hline \multicolumn{3}{|l|}{ MANUFACTURING } \\
\hline MKEK & Machinery and chemicals & $100.00 \%$ \\
\hline DMO & Office supplies & $100.00 \%$ \\
\hline SUMER HOLDING & Textiles & $100.00 \%$ \\
\hline SUMER HALI & Hand carpet & $100.00 \%$ \\
\hline SEKA & Pulp and paper & $100.00 \%$ \\
\hline \multicolumn{3}{|l|}{ MINING } \\
\hline TTK & Coal mining & $100.00 \%$ \\
\hline TKI & Lignite mining & $100.00 \%$ \\
\hline KBI & Copper & $100.00 \%$ \\
\hline ETI MADEN & Mining industry & $98.36 \%$ \\
\hline TDCI & Steel Industry & $100.00 \%$ \\
\hline \multicolumn{3}{|l|}{ ENERGY } \\
\hline TEIAS & Electricity transmission & $100.00 \%$ \\
\hline EUAS & Electricity generation & $100.00 \%$ \\
\hline TETAS & Electricity contracting \& wholesale & $100.00 \%$ \\
\hline TEDAS & Electricity distribution $\&$ retail sale & $100.00 \%$ \\
\hline TEMSAN & Electromechanic equipment & Subsidiary $^{4}$ \\
\hline KEAS & Electricity generation & $100.00 \%$ \\
\hline YEAS & Electricity generation & $100.00 \%$ \\
\hline \multicolumn{3}{|l|}{ PETROLEUM } \\
\hline TPAO & Crude oil exploration and production & $99.98 \%$ \\
\hline BOTAS & Oil pipeline & $100.00 \%$ \\
\hline PETKIM & Petrochemicals & $54.36 \%$ \\
\hline TUPRAS & Petroleum refineries & $51.00 \%$ \\
\hline DITAS & Maritime tanker transport & Subsidiary \\
\hline
\end{tabular}

\footnotetext{
${ }^{4}$ A subsidiary is an SEE wholly owned by another SEE
} 


\begin{tabular}{llr}
\hline \multicolumn{1}{c}{ State Enterprise } & \multicolumn{1}{c}{ Activity } & \multicolumn{1}{c}{$\begin{array}{c}\text { State } \\
\text { Share }\end{array}$} \\
\hline AGRICULTURE & & \\
TUGSAS & Fertilizer & $99.97 \%$ \\
TSFAS & Sugar processing & $99.98 \%$ \\
TMO & Soil products & $100.00 \%$ \\
CAYKUR & Tea processing & $100.00 \%$ \\
TEKEL & Tobacco and alcoholic beverages & $100.00 \%$ \\
TIGEM & Agriculture & $100.00 \%$ \\
EBUAS & Meat, fish processing & \\
& & \\
TRANSPORTATION & & $100.00 \%$ \\
TCDD & Railway services & Subsidiary \\
TUDEMSAS & Railway transportation equipment & Subsidiary \\
TULOMSAS & Railway transportation equipment & Subsidiary \\
TUVASAS & Railway transportation equipment & $100.00 \%$ \\
DHMI & Airports administration & $100.00 \%$ \\
KIYEM & Cost security & $100.00 \%$ \\
TDI & Seaports administration & $75.17 \%$ \\
THY & Airlines & \\
COMMUNICATION & & $100.00 \%$ \\
PTT & & $100.00 \%$ \\
TURK TELEKOM A.Ş. & Post, telegraph & $100.00 \%$ \\
TURKSAT A.S. & Telecommunication &
\end{tabular}

Source: Undersecretariat of Treasury

budget, investment program and its financing needs. Both public enterprises and state banks undertake quasi-fiscal activities (QFA) on behalf of the government, which are compensated onbudget (see paragraphs 5 and 9).

\section{Government relations with nonfinancial public corporations and the private sector}

\section{Public nonfinancial corporations do carry out some QFAs, and these are made} transparent in the budget. The QFAs include the purchase of agricultural produce at nonmarket prices, and the provision of goods and services on noncommercial terms. The government is required to appropriate for these activities in the budget ("duty losses") and they have declined significantly since 2001 , from 0.4 percent to about 0.1 percent of GDP in the 2005 budget. Losses from duties are audited by the Treasury prior to payment. If they exceed the appropriation in the budget, for instance due to the government requiring a higher agricultural support price, the budget contingency can be drawn on. Prior to 2003 advance payments could also be made against the following years' appropriation. This mechanism allowed duty losses to build up in enterprises, uncompensated, only to be retired in subsequent years through netting operations (for instance, against tax or dividend arrears). These operations, which have declined over the last five years, have been shown in the Budget Law, but not adequately explained. A recent amendment to the Public Debt Management Law, however, would move these, and any other netting operations, off-budget. 
6. The legal framework for privatization is clear but modalities for the payment of receipts to the budget lack transparency. The Law on Privatization (\#4046) defines the methodologies and norms for privatization. An annual plan alerts potential bidders to the types of assets offered for sale, and tenders are well-publicized. A tender committee drafts the specifications and method by which the decision on sale will be made, and all specifications are available through the Privatization Authorities' (PA's) website. The Council of Ministers $(\mathrm{COM})$ does have some discretion in the process: it sets any pre-qualification requirements by decree, and can cancel a transaction if bids do not surpass a minimum valuation. ${ }^{5}$ Transactions are audited by the High Auditing Board, which reports directly to the National Assembly. Bidders, and related parties, have the right of administrative and judicial appeal (there have been no recent instances of such). The privatization process is managed by the extrabudgetary PA. This fund can borrow (by permission of the High Privatization Council). It incurs all expenses associated with the privatization process and except when otherwise specified by law, accrues all receipts. It maintains a separate bank account in Ziraat bank. The receipts, along with the dividends it receives from some enterprises, are used to subsidize the losses or finance the investment program of others. The amount of dividends remitted to the budget (Treasury) is jointly decided upon by the PA and Treasury on a discretionary basis.

\section{The framework for government regulation of the nonfinancial private sector has} improved, but regulations can impose significant quasi-fiscal burdens. Since 1999, the government has created independent self-financing bodies to take over regulatory functions from line ministries, including the Ministries of Agriculture, Energy, and Communications. The new regulatory boards have a legal basis and clear objectives to guide their decisions, which can be appealed to administrative court. The general legal framework for private sector activity - covering labor laws, property registration, contract enforcement, and investor protection - has been relatively stable. However, long processes of uncertain duration have created concerns in areas such as patent protection and contract enforcement. The government has not publicized estimates of the costs and benefits of government regulations, even though in some cases they appear to impose significant fiscal burdens on the private sector. For instance, a labor market regulation imposing a cost of firing equal to 112 weeks of wages appears to substitute for ineffective unemployment insurance. ${ }^{6}$

\section{Government relations with the central bank and public financial sector}

8. Since late 2001, the CBT is prohibited by law from purchasing government securities in the primary market, and from extending an overdraft facility to the government or to public institutions. The one exception is the Savings and Deposit Insurance Fund, which can apply for a loan on market terms in extraordinary conditions (for instance, if funds are required to take over a bank). In this instance, the loan would have to be approved by the CBT's Board of Directors. The CBT is required to remit all profits, after reserves, to its shareholders in the form of dividends (the government is the largest shareholder, with 54 percent of the equity). Conversely, commercial law requires

\footnotetext{
${ }^{5} \mathrm{~A}$ valuation committee communicates a minimum value to the tender committee in advance of the sale.

${ }^{6}$ World Bank, “Turkey: Doing Business in 2005,” Washington: World Bank, 2004. To the extent businesses avoid this quasi-fiscal burden, the informal economy grows, undermining a key government objective.
} 
compensation for losses, although these have not been paid recently (reflecting the availability of some capital reserves). The Treasury does not compensate the CBT for payment services rendered, and the CBT does not pay any interest on government deposits (with the exception of the balance on the risk account).

9. Public financial corporations carry out some QFAs but, just like for nonfinancial corporations, most are transparently included in the budget. The duties include subsidized lending to students, small businesses and the agricultural sector. The government is required by law to appropriate for subsidized bank lending, separately for each bank. State banks management determines eligibility for loans, and once the appropriation is exhausted, the activity must stop. State banks bear all default risk. Subsidized bank lending has declined from about 0.2 percent of GDP in 2001 to far less than 0.1 percent of GDP in the 2005 budget. The credit and dormitories revolving fund also loans money to students on favorable terms and with little effort at collection enforcement (repayment rates are about 30 percent). It is funded by a budget transfer, which amounts to a little over 0.2 percent of GDP in 2005 . The PFMCL mandates that it should be fully incorporated into the Budget.

\section{Fiscal management relations among the branches of government}

\section{The fiscal roles of the executive and legislative branches of government are} clearly defined. Article 162 of the Constitution instructs that the executive (the COM) will submit a draft of the budget to the National Assembly 75 days prior to the beginning of the fiscal year. After consideration by the budget committees, the draft budget is submitted to a full vote prior to the beginning of the fiscal year. A provision prohibits parliamentarians from suggesting changes that would affect the overall level of expenditure. The constitution mandates (Article 164) that draft final accounts of fiscal outturns of central government be submitted to the National Assembly within 7 months of the end of the relevant fiscal year. The constitution (Article 160) also charges the Turkish Court of Accounts (TCA) with auditing all accounts related to revenues and expenditures of government financed by general and subsidiary budgets. No judicial review of TCA decisions is permitted. The PFMCL (Article 41) also mandates that the Ministry of Interior (MOI) is responsible for the production of an evaluation report of local governments' accountability reports which must be submitted to the TCA and made public.

\section{Fiscal management relations among different levels of government}

11. The responsibilities of different levels of government are generally well-defined but a number of provisions introduce an element of risk for municipalities. The new legal framework for subnational governments consists of three laws (see Box 2) which have already been approved by Parliament. A new framework legislation was also adopted by Parliament in 2004, but the President has challenged the constitutionality of certain articles. Expenditure functions of municipalities are generally well-defined in the laws. The responsibilities are comparably small, and important functions such as education and health are not decentralized. Important tax-expenditure links are missing such as penalty fees for traffic control, which are levied by the central government. 


\section{Box 2. Subnational Government in Turkey}

Turkey has a tradition of centralized government; the share of local finance is only 4 percent of GDP, although the responsibilities of the municipal sector are expanding.

There are 81 Provincial Administrations in Turkey that are not considered to be part of local administrations however. Each province is administered by a governor appointed by the COM and approved by the President. The provincial government consists of the governor and five members from amongst the Provincial Council, whose members are elected by popular vote. Provincial administrations have a coordinating role within their province, but no supervisory role as to the municipalities located in their territory.

There are also 81 Special Provincial Administrations that are governed by Law No. 5302 of February 22, 2005. Provincial functions fall into two parts: (i) General provincial functions such as services for meeting health requirements, agriculture, industry and trade; environmental planning of the province, public works and settlement. And (ii) municipal functions for the rural areas outside municipal jurisdictions. They also provide water and sewage services outside municipal boundaries. Although there is interaction between Provincial Administrations and Special Provincial Administrations, they remain two separate administrative structures.

Municipalities fall under the Law No. 5393 of July 3, 2005. There are 3225 municipalities in the country, with a prescribed minimum population of 5,000 persons, covering about three fourth of the country's territory. Smaller settlements are considered villages, and fall directly under the authority of provincial administrations. The municipalities' executives (mayors) and local assemblies are elected by popular vote. According to Article 14 of the law, municipalities must primarily provide urban infrastructure services, and important functions such as education and health, often decentralized elsewhere, are not decentralized in Turkey.

There are 16 Metropolitan municipalities and they are subject to Law No. 5216 of July 10, 2004. They are formed from urban areas whose total population exceeds one 750,000 persons. Municipalities continue to exist under the umbrella of the metropolis (for instance there are 34 municipalities in the capital city Ankara). Their responsibilities include strategic urban planning and other metropolitan services including water and sewerage.

\section{The municipal grant system is rules-based and generally transparent and} predictable by design, although the transfer pool is subject to macroeconomic risks and discretion. Municipal transfers are regulated by the Law on Municipal Revenue (Law No 2380) which fixes the shares for allocating tax revenue to subnational entities. ${ }^{7}$ However, there have been variations over the last years, which may entail some discretion - and budgetary risk for subnational governments. At the discretion of the MOF, an adjustment of tax shares was made in 2002 and 2003 when the property tax base had been revalued. The increase in property tax returns was compensated by a reduction in tax shares under the economic programs. Moreover, actual municipal tax shares differ from legislation, especially for metropolitan governments. The system of horizontal allocation is however simple and generally functional and transparent, thus providing some stability and predictability. The allocation of tax sharing entitlements is effected through Iller Bank. In total, municipalities cover about 47.9 percent of their outlays from tax sharing grants. Own tax revenues account

\footnotetext{
${ }^{7}$ The tax pool for subnational governments is closed and well defined. Two sub-pools are formed for provinces (they obtain 1.12 percent) and municipalities ( 6 percent).
} 
for merely 10.2 percent of municipal revenue, the remainder being nontax revenue including factor income (see Table 2).

Table 2. Structure of Local Governments' Consolidated Accounts 2004 (preliminary)

\begin{tabular}{lcc}
\hline & YTL Billion & $\begin{array}{c}\text { In percent } \\
\text { of total revenue }\end{array}$ \\
\hline Total revenue & & $\mathbf{1 0 0 . 0}$ \\
Tax sharing, of which & $\mathbf{1 6 . 7}$ & 47.9 \\
Municipalities & 8.0 & 26.3 \\
Metropolitan Municipalities & 4.4 & 15.6 \\
Provincial Administrations & 2.6 & 5.4 \\
Water \& Sewerage Administrations & 0.9 & 1.2 \\
Own revenues & 0.2 & 10.2 \\
Nontax revenue \& factor income & 1.7 & 42.5 \\
Total expenditures & 7.1 & $\mathbf{1 0 1 . 2}$ \\
Recurrent expenditures & $\mathbf{1 6 . 9}$ & 54.5 \\
Capital outlays & 9.1 & 46.7 \\
Deficit, of which & 7.8 & $\mathbf{1 . 2}$ \\
Foreign net borrowing & $\mathbf{0 . 2}$ & -2.4 \\
Domestic net borrowing & -0.4 & 3.6 \\
\hline
\end{tabular}

Source: SPO

13. Iller Bank is a government agency that provides municipalities with financial and technical support for infrastructure development. However, some of its operations are not transparent and there is scope for interference. ${ }^{8}$ All members of Iller Bank can apply for loans in principle, but in practice the bank focuses its lending operations on smaller and medium-sized municipalities. Loans are capped and small, and they are typically tied to projects, deterring wealthier municipalities from seeking such loans despite favorable terms (9 percent interest in 2005, which includes a nonrecorded subsidy). In case arrears are accumulated by a municipality either to the Treasury or to the Iller Bank, the bank has the right to "claw back," at rates determined by the Ministry of Finance, up to 40 percent of the transfer entitlement of that municipality. However, there is a degree of discretion in how the Iller Bank policy (including by exceeding the 40 percent limit) is applied, and this has introduced a degree of uncertainty and lack of transparency in intergovernmental fiscal relations. ${ }^{9}$ There are strategic plans to restructure Iller Bank as it is expected to play a role in implementing future EU (European Union) structural and regional programs and helping municipalities to meet EU standards. The Prime Minister's office expects to submit this legislation to parliament in 2005.

\footnotetext{
${ }^{8}$ Iller Bank does not take private deposits nor take loans from the capital market, but is in the process of finalizing a \$275 m World Bank loan for water projects. Its capital stock is accumulated through compulsory annual equity contributions by all members, corresponding to 5 percent of their respective current revenuesboth tax shares and own revenue (Iller Bank Law \#4759).

${ }^{9}$ These "claw backs" are activated in accordance with Law \#6183 on the collection of government receivables.
} 
14. Municipal borrowing rules are a cause for concern. The borrowing authority of subnational governments has to be approved by the Ministry of Interior for internal debt exceeding 10 percent of their revenue (within certain limits on the level of the stock), and is subject to administrative approval by the central government for external debt (see Annex for details). However about 900 (of some 3,200) municipalities have already reached their maximum debt stock limits (up to 100 percent of annual revenue for municipalities and 150 percent of revenue for metro municipalities). There are substantial payment arrears on servicing existing municipal debt, which creates uncertainties for fiscal sustainability. These risks are exacerbated by municipal public enterprises, which may incur unrestricted debt. At present, a Commission consisting of representatives from the MOF, the Treasury, the MOI, the SPO, Social Security institutions, Iller Bank, and the Court of Accounts attempts to restructure outstanding municipal debt and payment arrears. Restructuring will be achieved by netting debt and payables and receivables. The remainder of municipal debt will be collected through deductions from tax sharing entitlements.

\section{Accounting and reporting of local government operations could be improved.} Local governments report their final accounts to the MOI, which however does not publish information on budget outcomes. Parliament may obtain information from the MOI on request. Available short term information on financial operations of local governments is based on surveys conducted by the SPO as discussed below. More comprehensive data (the final accounts of municipalities and Special Provincial Administrations) is available from the Statistical Office, but is only available with a lag of two years, yet often longer. Information on municipal government enterprises, which are growing in number and size, is incomplete.

\section{The legal and administrative framework for budget management}

\section{Turkey is in the process of implementing a new budget systems law but this} would not have precedence over other laws (Box 3 describes the changes envisaged under the new law). ${ }^{10}$ Although the PFMCL has the appearance of a framework organic budget law, other unrelated legislation can include exemptions to its provisions and it is therefore difficult to track overall developments in budgetary legislation, in particular to cost their implication on the budget. The inclusion of exemptions in seemingly unrelated legislation appears to be a frequent and leads to a lack of transparency in the legal framework for budget management. Another related issue is the frequency with which amendments to the PFMCL are tabled. There are currently over fifty amendments being considered even though the law is under two years old.

\footnotetext{
${ }^{10}$ The lack of a hierarchical structure to primary legislation is not uncommon. In other countries, such as France, the primacy of the Organic Budget law is embedded in the Constitution. Many countries do however have procedural rules that prohibit consideration in the legislature of laws that include an amendment of a principal law in that area. With such a rule, an inconsistent law put to a vote could be subject to a point of order (by a single member) and ruled out of order by the chair of the legislature.
} 


\section{Box 3. Proposed Reforms to the Turkish Budget Process}

The Turkish budget process is currently undergoing a period of considerable change. New legislation covering the budget process (the Public Financial Management Control Law - Law No. 5018) was adopted in December 2003 to replace the existing General Accounting Law of 1927. It will be a challenge, however, to implement all the provisions of the law by the deadline of 2007. The main changes in the budget process include:

- Increased coverage of the central government budget. The existing system excludes many institutions such as EBFs, revolving funds, social security institutions and foundations. The new PFMCL, when fully implemented will abolish the remaining EBFs and revolving funds and incorporate their activities in the central government budget on a gross basis. Remaining weaknesses will include the exclusion of, foundations, and Iller Bank. Social security institutions will also remain outside of central government budget coverage although this is not inconsistent with the provisions of GFSM 2001.

- Adoption of a medium-term budget. The existing budget process is based on an annual budget horizon whereas the PFMCL provides for the adoption of a medium-term horizon.

- Development of performance based budgeting. The existing budget system is input based with appropriations being approved on the basis of economic and functional input classifications. The PFMCL envisages the adoption of a performance based budgeting system which will necessitate the re-orientation of budget proposals to a more programmatic approach based on outputs and outcomes. And,

- A more devolved system of budget management. The current financial management system is tightly controlled by the central government both at the budget preparation and execution stages. The new PFMCL envisages a system where the budget agencies take more control over the formulation and execution of their budgets. Spending agencies will develop their internal control function and the existing central ex-ante control apparatus will be dismantled with a focus on ex-post external audit and assessment of performance.

17. The PFMCL will improve the system of budget management, but three institutions will continue to be involved in it. ${ }^{11}$ The Ministry of Finance (MOF) will remain responsible for budget preparation, budget execution, accounting and reporting, and revenue collection; the SPO will continue to prepare and monitor the public investment program, develop the macroeconomic framework, and report public sector statistics; and the Treasury will remain responsible for cash and debt management, operations of most EBFs and stateowned enterprises, and relations with international financial institutions. While close cooperation among these organizations is the norm, the spreading of responsibilities across institutional lines, also discussed in the 2000 fiscal ROSC, has a bearing on the efficiency of the policymaking process.

\section{Coverage of the budget has improved since 2000, but full coverage of central} government institutions remains incomplete (see Box 1). Under the existing budget system, the coverage of central government is limited to the general budget and annexed budget agencies. The number of extrabudgetary and revolving funds has, however, been

\footnotetext{
${ }^{11}$ Until the adoption of the 2005 budget, management procedures outlined in the General Accounting Law of 1927 and associated government regulations have been used as the basis for budget formulation. The procedures outlined in the PFMCL are due to be adopted for the 2006 budget.
} 
considerably reduced since the 2000 Fiscal ROSC. ${ }^{12}$ Nevertheless, 5 EBFs remain, together with over 1,455 revolving funds which still conduct off-budget operations. ${ }^{13}$ These funds only report surpluses as transfers to the general budget, or the financing of deficits as transfers from the general budget. A large number of "foundations" closely linked to individual ministries and public agencies, collect resources through a number of means, including through the provision of public services, and operate outside the Budget framework. ${ }^{14}$ Their activities are not reported. There are also ten regulatory bodies which are currently not included in the central government budget. ${ }^{15}$ Social security institutions' expenditures accounting for about 11 percent of GDP are outside central budget coverage although this is not inconsistent with GFS2001m guidelines. ${ }^{16}$ They report to the Ministry of Labor and are audited by the High Audit Board of the Prime Ministry, but the reports are not publicly available.

\section{The full implementation of the PFMCL would apply the same budget systems to} all general government and eliminate most, but not all, remaining omissions in coverage of central government. The new PFMCL includes all of the central government budgetary and EBFs under a single budgetary framework (Charts I-III institutions). The remaining revolving funds are due to be abolished by 2007 and incorporated in the budgets of their controlling agencies. Moreover, some foundations will continue to be excluded from the budget process, although article 40 of the PFMCL has attempted to curtail their activities. ${ }^{17}$ It appears that there are ways to circumvent the legislation and, to date, such foundations still appear to be actively soliciting "donations". Chart IV institutions -the social security institutions- will continue to be classified as a separate sub-sector of general government.

20. Public debt and cash management are regulated under legislation separate to the main budget systems legislation. In March 2002, Parliament approved a new law on public finance and debt management (Law no. 4749). The law states that Treasury is the single

\footnotetext{
${ }^{12}$ In 2000, there were $81 \mathrm{EBFs}$ and over 3,000 revolving funds.

${ }^{13}$ The five EBFs are established under separate legislation. These are the Privatization Fund Law (4046), the Defense Industry Support Fund Law (3238), the Social and Solidarity Support Fund Law (3294), the Promotion Fund Law (3230), and the Savings Deposit Insurance Fund Law (3182).

${ }^{14}$ Foundations are institutions established to improve the welfare of public servants. Their legal basis is derived from the Law on Foundations (5072). Traditionally, the foundations have been attached to central government institutions or agencies although the PFMCL appears to try to disassociate the foundations from the public authority to which they have been attached. The foundations collect revenue through requests for "voluntary" contributions from the public for providing public services associated with the underlying central government agency. Donations to the foundations tend to speed up delivery of such services. Expenditures of the foundations are mainly related to improving the working conditions and benefits of the staff of the underlying government agency.

${ }^{15}$ See paragraph 5 .

${ }^{16}$ Section 2.43 of the GFS2001m permits the classification of social security funds as a separate sub-sector of general government

${ }^{17}$ Article 40 provides that all donations and grants related to delivery of public services should be recorded as revenues in the budget.
} 
borrowing authority for the central government and establishes a comprehensive and more transparent framework for guarantees. The EBFs are not however considered part of central government in this definition and the Privatization Fund, the Defense Industry Support Fund, and the Savings and Deposit Insurance Fund have all been granted power to borrow in accordance with the laws regulating their establishment. ${ }^{18}$ Since 2000 , the Treasury has been disclosing information about all called and outstanding guarantees on its website. However, a recent amendment to the law has allowed netting operations of public debt against public receivables to be conducted off-budget. In addition, the PFDML does not have specific provisions on Public Private Partnerships (PPPs).

\section{The legal and administrative framework for tax policy and administration}

\section{The taxation framework has improved, but remains complex and subject to} significant discretion. ${ }^{19}$ Since 2000 , the government has introduced inflation accounting and eliminated a number of ad hoc inflation compensation mechanisms (including long lags in collection). Excise taxation has been significantly simplified with the introduction of the Special Consumption Tax, and the concurrent consolidation of many small earmarked excises. However, some key issues remain to be addressed, including:

- $\quad$ Excessive complexity of existing legislation: there remain a large number of exemptions or relevant provisions spread across many different laws, which is compounded by many overly complex regulations (for example minimum employee declarations for those building houses);

- $\quad$ Significant policy discretion: most tax laws give the COM wide latitude to change rates within year without going to Parliament. For example, any good can be shifted among the various rates of VAT. While some "temporary" but annually renewed taxes have been removed, temporary exemptions for specific sectors (e.g., excises on automobiles) remain an issue and complicate the assessment of tax obligations;

- $\quad$ Significant discretion in administering the tax system: the complexity often leads taxpayers to request comments from the tax authorities. These private notices are not legally binding, can become the de facto interpretation of the law for the case in hand, but do not create precedent (consistency is not assured). They may also not be published (the bi-monthly Regulation bulletin only covers some of them); and

- $\quad$ Recurrent use of tax and social security amnesties: some 37 tax amnesties have been carried out since the founding of the modern Turkish state, creating major uncertainty and disincentives about de facto tax obligations and payment requirements.

\footnotetext{
${ }^{18}$ See footnote 13

${ }^{19}$ The major tax laws include the: Income Tax Law (193), Corporate Income Tax Law (5422), VAT Law 3065, Special Consumption Tax Law (4760), and the Tax Rebates Law (2978). The PFMCL provides that the legal grounds of the revenues of the public administrations be indicated in their budgets. Similarly, policy and objectives are to be published.
} 


\section{Extensive tax expenditures are not reported, but would be under the PFMCL.}

The tax administration has undertaken some study of the cost of tax expenditures, but has also yet to finalize estimates. Preliminary data suggest that investment tax incentives through special economic zones and for regions may cost the Government YTL145 million in 2004 and the deduction of pension contributions from Personal Income Tax (PIT) and Corporate Income Tax (CIT) could cost YTL 2,200 million (0.6 percent of GDP). Tax forms are being redesigned to capture information relevant to the calculation of other tax expenditures. However, information in unlikely to be complete by end-2005, and the information presented with the 2006 budget may accordingly be less than complete.

\section{The revenue collecting agencies are divided across ministries and some} functional fragmentation remains. The new tax administration law, in place since early May 2005, provides for a semi-autonomous tax administration located under the MOF while the customs administration is a single organization located under the Prime Ministry. While the tax and customs administration employ a common taxpayer identification number, the ability to exchange information is only automatic in the case of Value Added Tax (VAT) export refunds. ${ }^{20}$ The new tax administration law, once fully implemented, will help consolidate the tax administration within the MOF (local tax offices, which previously reported to local officials, are now under the direct control of the tax administration). The law will also mandate a functional organization. However, audit remains fragmented, with responsibilities overlapping between revenue controllers (in the tax administration), the Bureau of Expert Accountants (in the MOF), and Finance Inspectors (also in the MOF). An audit coordination unit was set up in 2002 to help minimize the problems associated with fragmentation, and an annual audit plan was developed. The customs department is also organized functionally, with separate units for enforcement, audit, and taxpayers services. Both the tax and customs administrations are financed by annual appropriations under the budget law. The tax administration publishes an annual report available on its website. This does not include information on compliance costs, but does indicate the cost of administration, which amounts to about 0.8 percent of total revenue collected.

\section{Taxpayers' legal rights are well defined and published on the web sites of both} the tax and customs administration. ${ }^{21}$ The powers and limitations of tax officials to search, demand third party information, and enforce arrears are specified in laws and regulations. Administrative and judicial reviews are available to taxpayers. Customs decisions can be appealed to, successively, the local office, the regional office, and, subject to a threshold on the value of the appeal, to the customs headquarters office. At any point, the taxpayer can instead seek redress through the court system. However, judicial decisions on tax issues take an average of two years. The tax administration does not have a mechanism for requesting advanced tax liability rulings, but taxpayers have the right to ask for an interpretation. The customs administration does provide binding rulings on presentation of a written petition.

\footnotetext{
${ }^{20}$ The Law on Taxpayer Identification Numbers (4358) establishes their use, and about 35 million of them have been issued to taxpayers. The tax identification number (TIN), however, is not used for the collection of social contributions (which is separately undertaken by the social security organizations).

${ }^{21}$ The tax collection regulations are established in the Tax Procedure Law (213), and the Public Receivables Collection Law (6183).
} 


\section{Public servants' code of behavior and anti-corruption activity}

\section{Public servants are subject to a code of behavior, but some important gaps exist.} The Civil Service Law (\#657) defines standards of conduct for civil servants, and the more recent Law on Establishing the Civil Servants Ethical Board (\#5176) has just recently established an ethical board and commission in each line agency charged with promulgating a code of conduct to employees. This includes provisions against accepting resources (mirroring the provisions in the PFMCL) and against favoring former public servants. Disciplinary committees in ministries are to follow up complaints from the public, and the Ethics Board is to publish any decision against a civil servant (although the system is new and has not yet been tested). The Finance Inspectors Board in the MOF has for many years performed an anti-corruption function, and it focuses on severe and important corruption cases. A key weakness in the code of behavior is the ability of some former civil servants, in particular tax auditors, to immediately upon resigning their position, represent clients in dealing with their former agency. ${ }^{22}$

\section{B. Open Budget Preparation, Execution, and Reporting}

\section{The budget preparation process: clarity and consistency of process and presentation}

\section{The existing system of budget preparation is fragmented, largely incremental} and based on an annual horizon although there are plans to move towards a multiannual budgeting system. ${ }^{23}$ In June of each year, the SPO prepares a macro framework, which is issued to the spending ministries together with budget guidelines drawn up by the MOF and soft expenditure ceilings agreed with the High Planning Council. To date the ceilings have mainly been of an incremental nature with few revisions to revenue or expenditure ceilings to reflect changing government priorities. Negotiation between the spending ministries and the MOF (for recurrent budget items) and the SPO (for investment projects) take place between July and August of each year. Investment proposals of spending agencies need to comply with the five year development plan produced by the SPO. By the end of August, the finalized budget proposals are sent by the spending institutions to the MOF for consolidation before the draft budget law is submitted to the Council of Ministers. Assessment of the impact of proposed investment projects on future recurrent expenditures is weak as it is not considered a major issue, given the annual budget horizon. ${ }^{24}$ Little supporting documentation is presented with the budget to assist the legislature and the public to better understand the financial position of the government. The content of the existing

\footnotetext{
${ }^{22}$ Law 2531 in general limits the jobs which former civil servants can undertake, but it is superseded in the case of former tax auditors by the Chartered Accountants Law (\#3568).

${ }^{23}$ As the PFMCL has not yet been fully implemented, the existing budget preparation procedures were used for the 2005 budget. Commencing with the 2006 budget three year estimates are being produced for the 2006-2008 period.

${ }^{24}$ With investment projects the large impacts of investment projects on recurrent budgets tend not be felt in the current year but rather in future years as maintenance and other recurrent costs need to be factored in as the investment projects come on stream.
} 
budget documentation is largely quantitative, based on inputs in accordance with economic and functional classifications of revenues and expenditure.

\section{The PFMCL, when fully implemented, will address some, but not all, of the} weaknesses inherent in the current system of budget preparation. ${ }^{25}$ The PFMCL provides for a medium-term performance based budgeting system that will focus on achievement of government policies. ${ }^{26}$ Budgets will be formulated within the framework of the strategic plans which each spending agency is mandated to produce. A considerable amount of supporting documentation will also be included in budget documentation which should increase the level of transparency of public finances. ${ }^{27}$ As already indicated, however, the existing fragmentation in the budget formulation process will complicate the analysis of the linkages between investment budget related expenditures and the recurrent budget. If this system is to continue, it will be necessary to strengthen the coordination between the different institutions during the budget formulation phase. Although best international practice would dictate that a single institution should take control of the coordination of the budget formulation process there are a number of notable exceptions. ${ }^{28}$ Coordination is however key. Training of officials to implement the new system will also be a key component to ensure success of the initiative.

\section{The macroeconomic framework and policy basis for the budget}

\section{The fiscal position is monitored through the primary surplus and policy} discussions also focus on the public debt ratio. The broader public sector primary surplus receives considerable attention in Turkey, largely because it features prominently in the IMF program. The IMF program definition does exclude some components which are more recent (e.g., regulatory boards), and foundations (due to data gaps), but includes local governments, although incomplete data and lags in data collection make the relevance of this component uncertain. ${ }^{29}$ The authorities have also set a medium-term policy target of reducing the public debt to GDP ratio by 10 percent over the next three years, and have indicated that to do so they will maintain a public sector primary surplus (IMF program definition) of 6.5 percent of GNP. The overall balance for both the public sector and central government is monitored, but

\footnotetext{
${ }^{25}$ The say $2000 i$ web-based automation system is capable of recording transactions on a cash or an accrual basis although the coverage of the system is limited to the general and annexed budget government agencies at present.

${ }^{26}$ Articles 9 and 16 of the PFMCL.

${ }^{27}$ These include the medium-term fiscal strategy, annual economic report, schedule of revenues foregone due to tax exemptions, debt management report, details of previous two years budget outturns and two year forward estimates, budget of central government agencies and a list of institutions deemed outside the scope of general government. These documents are expected to be included with the 2006 budget.

${ }^{28}$ For example, Brazil.

${ }^{29}$ Quantitative conditionality under the IMF program focuses on a narrower and more monitorable definition comprising the central government (including annexed agencies); the social security institutions; the defense, privatization and social aid funds; and 25 major state enterprises.
} 
high inflation and high and variable rates of interest have at times reduced its relevance. ${ }^{30}$ With the recent successful emphasis on macroeconomic stabilization, the authorities have however increasingly focused on the overall balance.

\section{Box 4. The Budget Preparation Process}

The fiscal year is the calendar year (Article 3 of the PFMCL, Law No. 5108). Main steps in the process:

Due dates

May

End May

June 15

End-June

End July

August/September

1st Week of October

October $17(\max )$

October 17

Prior to beginning of

fiscal year

15 days after publication of Central Government Budget

Law
Activities

SPO presents initial macroeconomic framework in budget guidelines

Medium-term program prepared by SPO and adopted by $\mathrm{COM}$

Medium-term fiscal strategy drawn up by MOF and adopted by High Planning Council

Budget call and budget preparation guide prepared by MOF and Investment Circular and Investment Program Preparation Guide prepared by SPO

Line Ministries prepare recurrent budget proposals and send to MOF

Line Ministries prepare investment spending proposals and send to SPO

Negotiation with Line Ministries on proposals for inclusion in Public Investment program -SPO

Recurrent Budget- MOF

Finalization of Macroeconomic indicators and budget envelope by High Planning Council

Government Draft Budget Bill approved by Council of Ministers

Government draft budget bill presented to Parliament*

Budget approved by Turkish National Assembly and Central Government Budget Law published in Official Gazette

Public Investment Program Published in Official Gazette
Legal basis

Article 16 of PFMCL Article 16 of PFMCL

Article 16 of PFMCL

Article 17 of PFMCL

Article 17 of PFMCL -although exact dates not specified

Article 18 of PFMCL

Article 18 of PFMCL

Article 162 of the Constitution and Article 18 of PFMCL

Article 162 of the Turkish Constitution

Article 19 of PFMCL

* Regulatory and Supervisory agencies submit budget directly to Turkish National Assembly by endSeptember

\footnotetext{
${ }^{30}$ The compensation for loss of real principal value provided by nominal interest payments blurs the distinction between the above and below the line items. It is possible to correct for this problem by cleansing data for the impact of inflation, but such adjusted data are not published in Turkey.
} 
29. The macro framework for the budget is developed by the SPO. The macroeconomic model used is published and the main macroeconomic assumptions are presented, some implicitly. Information about GDP growth, aggregate savings and investment, inflation, export and import growth, and energy prices are published with the budget. Details of wage and exchange rate forecasts are not explicit. Forecasts for growth and inflation are set as targets, but checked against a macro model for consistency with input from CBT, Treasury, and MOF. Macro forecasts are updated quarterly, and the second quarter update feeds into the budget review. Initial annual forecasts are made in May and are the basis for the budget call and investment guidelines (June). The macro framework is updated in September ( $3^{\text {rd }}$ quarter) and feeds into a final budget revision. The recent macroeconomic stabilization has helped reduce the large changes in the macro framework which used to occur late in the budget process and undermine effective budgeting.

\section{Medium-term planning and analysis of fiscal risks}

30. The economic and financial analysis presented in the Budget, which is currently limited to one year projections, will include a medium-term framework in 2006 . The medium term macro framework has recently been developed by the SPO in anticipation of the PFMCL requirement for a three-year medium term framework covering both revenues and expenditures. This could constitute the basis for a rolling medium term expenditure framework. In addition, the preparation of the multi-year EU pre-accession economic program has contributed to the development of medium-term fiscal programming. There are no explicit fiscal rules with the exception of the conditionalities inherent to the program targets with the IMF.

31. There is currently no explicit costing of new policy initiatives included in the budget documentation. The PFMCL does not provide for such a statement and, although it requires the government to publish with the budget a "schedule of public revenues renounced due to tax exemption, exception, discounts and similar practices," this is not done at present. The debt management report, issued on a quarterly basis on the Treasury's website, includes a comprehensive analysis of guaranteed debt and treasury receivables. ${ }^{31}{ }^{32}$ The analysis includes yearly payment projections, based on the current guaranteed debt stock, the receivables stock and collections by the Treasury including a breakdown of their composition. There is no formal statement of fiscal risks in existing budget documentation.

\section{Clarity of control of budget execution}

32. Financial control and cash management practices are weakened by the existence of numerous bank accounts outside the "TSA"

\footnotetext{
${ }^{31} \mathrm{http} / / / \mathrm{www} \cdot$ treasury.gov.tr/indexe.htm

${ }^{32}$ The debt management report is one of the documents that should be included in budget documentation in accordance with Article 18 of the PFMCL.

${ }^{33}$ Following on from the recommendations of a report by an FAD technical assistance mission on "Implications of State Bank Reforms for Government Debt and Cash Management and for Central Bank Operations" (2005),
}

(continued) 
Single Account" (TSA) in the CBT, central government line budget agencies also have individual bank accounts in the CBT (line ministries mostly) and in the state banking sector. The Treasury maintains an account in Ziraat bank for transactional reasons, although the balances can be quite large. ${ }^{34}$ Ziraat is the only bank authorized to hold central government cash accounts, although it also holds accounts of other central government spending agencies. EBFs and revolving funds have their own bank accounts, separate from their controlling institutions, as do foundations. Both revolving funds and foundations may have accounts in private sector banks. Tax receipts are held, on interest free deposit, with commercial (private and public) banks for two to three days. These amounts are not available to the Treasury until they are deposited in the "TSA" in the CBT. Local government bodies hold accounts with other State banks which are completely separate from central government cash management operations.

\section{The absence of a system of commitment controls also weakens cash planning and} financial management functions. While the MOF allocates appropriations to line agencies on a quarterly basis, it has no information on commitments already entered into by these agencies. The ceilings on appropriations are not necessarily reflective of the cash available to line agencies as the Treasury also manages cash based on availability, irrespective of the appropriations released by the MOF. MOF accountants can authorize expenditure by spending agencies based on the quarterly releases of appropriations which could result in the build-up of arrears. The Treasury produces cash plans which are reasonably accurate but suffer from the lack of data on commitments. Coordination between the MOF and the Treasury is reasonably good, however, with a monthly meeting to try to coordinate appropriations and cash releases.

\section{Internal controls are currently characterized by an inflexible, centrally} controlled ex-ante inspection system. Accountants from the MOF are located in each spending agency to scrutinize and approve ex-ante all payment authorizations. The Financial Inspection Board is also tasked with performing ex-post controls on spending agencies government expenditures. Ex-ante controls were carried out by the TCA up to this year through the provision of payment visas for requested spending by the agencies. ${ }^{35}$. The GDBFC also performs an ex-ante control function.

\section{The PFMCL aims at reforming and improving the existing system through the} establishment of internal financial control functions within spending agencies, but there remains some uncertainty about the exact administrative arrangements. ${ }^{36}$ The internal control envisaged in the PFMCL dismantles the current system of centralized ex-ante control

a working group, representing relevant parties has been established, as at end June 2005, which includes in its remit a requirement to examine the issue of multiple bank accounts of spending agencies.

${ }^{34}$ The joint FAD/MFD TA mission on "Implications of State bank Reforms for Government Debt and Cash management and for Central Government Operations" -Diamond et al., estimated that average weekly balances of central government bodies accounts in Ziraat bank exceeded YTL 2.8bn in 2004.

${ }^{35}$ The ex-ante control function of the TCA is due to be abolished in 2005 in line with the move towards development of internal financial control and audit systems in the individual spending agencies.

${ }^{36}$ Articles 54-60 of PFMCL. 
and moves towards a more devolved system with an emphasis on financial control and internal audit units within spending agencies. Internal audit units will be monitored by the Internal Audit Coordination Board (IACB) which will be under the control of the MOF. ${ }^{37}$ It is anticipated that the role of the financial inspection Board in the MOF will diminish in time and that its remaining functions will concentrate on anti-corruption activities, although the speed at which this takes place remains uncertain. Performance and compliance audit functions will be devolved to the internal audit units and regular external audit from the TCA. In order not to lose the expertise of its current pool of financial inspectors, the MOF has proposed to assimilate them into these financial control units. ${ }^{38}$ Despite undoubted progress, the devolvement process is still at a very early stage of development and its planned completion by 2006 appears extremely challenging. The TCA is not currently a member of the Internal Audit Coordination Board although their opinion on draft legislation regulating the roles and responsibilities of the internal control function in general government entities has been sought. The lack of a formal participatory role in the supervision process could be regarded as a weakness of the new system and may make the TCA coordination of internal and external audit more difficult.

\section{In 2002, the Procurement Law (No. 4735) established an independent procurement agency to oversee all elements of the procurement process. The current} procurement framework is broadly consistent with UNICTRAL standards. Information on tendering requirements is readily available through the Procurement agency's website. Tendering mechanisms are legally required for large contracts; tender committees have independent authority; decisions of tendering committees are open to audit; and mechanisms exist by which bidders' complaints can be heard and settled. However, the procurement law has been subject to a number of amendments that have narrowed its scope since it was first introduced. ${ }^{39}$ For instance, consultancy services for the PA and the whole utilities sector in the State enterprises domain were removed. Further exemptions for certain institutions - for example, regional development banks - are under consideration.

\section{Civil service employment procedures are clear and well understood. The 1981} Law on Employment (No. 190) determines the number of civil service positions, while the annual budget law determines the actual level and distribution of employment. Hiring is subject to the approval of the State Personnel Directorate in conjunction with the MOF (for budget agencies), the SPO (extrabudgetary agencies), the MOI (local administrations) and the Treasury (state enterprises and banks). On a quarterly basis, a committee composed of representatives of the MOF, Treasury, SPO, and MOI collects data covering the consolidated budget, local governments, social security institutions, and state enterprises and banks. Civil servants are regulated by the Civil Service Law (No. 657), and defined as those public employees carrying out public services of a primary and continuous nature. The constitution protects those occupying civil service positions, effectively granting a lifetime job

\footnotetext{
${ }^{37}$ The IACB was established on June 30, 2004 in accordance with Article 66 of the PFMCL.

${ }^{38}$ An extensive training program is currently underway whereby the MOF is training spending agency trainers to assist with the capacity development effort in this area.

${ }^{39}$ For example, through Law No. 4964 (Law on the amendment of some laws) of July 2003.
} 
guarantee. $^{40}$ Entry into the civil service is subject to a state examination. There are nine service classifications (e.g., education or security), 15 grades and 3 steps in each grade. Public workers have a contract but do not occupy a civil service position, and are thus regulated by the Labor Law (No. 1475).

\section{The compensation system for civil servant is extremely complex and not} transparently managed. While it is broadly competitive with the private sector, compression can be severe. In addition to the basic wage, there are about 50 allowances, including by category of civil servant, by location and for individual circumstances (e.g., rank or foreign language). ${ }^{41}$ Both the basic wage and allowances are adjusted each year for inflation, by means of three coefficients that are published in the budget. However, little information on overall salaries is published, even within the government. Many allowances are not subject to taxation. The system also incorporates a number of in-kind benefits, including subsidized housing, food, and transportation, some of which are only available in certain ministries. Many of these benefits are recorded as spending on other goods and services and do not appear in the personnel budget. Studies using labor force survey data suggest that the average civil servant with less than 10 years experience enjoys a premium over (formal) private sector counterparts. ${ }^{42}$ Public workers also appear to enjoy substantial premia: in 2003, the ratio of the net wage of a public worker (i.e. after all deductions) to a comparable private sector worker was about $1.5 .^{43}$

\section{Clarity of internal control and independence of tax administration}

\section{Computerization has helped improve the revenue administrations' (RA) internal controls, but the RA's internal audit function has not yet been established. ${ }^{44}$ The tax administration has implemented the VEDOP II system and the customs administration has implemented the Sofix system. The latter now covers 98 percent of the customs administrations' offices. As a separate budget Agency, the establishment of an internal audit unit, reporting directly to management, is on the RA's agenda although, to date, the process has not commenced. The customs administration, which is located under the Prime Ministry, has its own internal audit unit. Periodic independent financial and compliance audits of the tax and customs administrations are undertaken as a routine part of national external audit.}

\footnotetext{
${ }^{40}$ Contract workers are also regulated by Law 657 (Article 4-B). They are supposed to be employed to fill temporary needs, and receive one-year contracts. However, the courts have ruled that, by virtue of the "civil service" positions that they occupy, they enjoy all benefits and protections of civil servants.

${ }^{41}$ Various laws determine the structure of and eligibility for allowances. The average employee receives about 7 or 8 allowances, which typically correspond to between 25 and 75 percent of total compensation.

${ }^{42}$ Tansel, Aysit "Public employment as a social protection mechanism.” ERF WP 0104, Middle East Technical University, 2001.

${ }^{43}$ Compression can also be severe: while the ratio of the highest to the lowest civil service wage in Turkey is about $7 \frac{1}{2}$, the ratio of the average public worker wage to the average civil servant wage is about $1 \frac{1}{2}$.

${ }^{44}$ Since the mission visited Ankara, the General Directorate of Revenues (GDR) in the MOF has been renamed as the Revenue Administration and its institutional status was changed to a semi-autonomous institution under the MOF.
} 
Performance audits are not conducted by TCA. The Finance Inspectors Board (MOF) can undertake performance audits, but does not publish them.

40. The national revenue administration does not have explicit legal protection from outside interference although its level of autonomy has improved; in particular the organization remains under the MOF, and the MOF approves the coordinated work program for tax audits. However, the new tax administration law, in place since early May 2005, has increased the level of autonomy. In particular, the head of the revenue administration now chairs the committee that decides on the treatment of tax arrears and arbitrates on the settlement of these arrears and associated penalties.

\section{Accounting and reporting on budget execution}

41. Since 2004, the annual general and annexed budget institutions have reported on budget execution in line with the GFSM 2001 classification. ${ }^{45}$ Although all public institutions prepared, and have been implementing, their 2005 budgets in accordance with the PFMCL, only the general and annexed budgets were submitted for the approval of the Parliament. GFSM 2001 codes have been incorporated into the master chart of accounts (COA) for transaction items, but this has not yet been done for balance sheet items. As indicated earlier however, the 2005 budget was prepared in accordance with the provisions of the General Accounting Law of 1927 and therefore, many government expenditures were excluded or only partially recorded in the budget estimates. ${ }^{46}$ While the new COA is GFSM2001 compliant, the budget classification system is still based on the GFSM 1986 system, which broadly aligns with the GFSM 2001 system but has some important differences. EBFs, social security funds, and local governments currently have separate accounting systems, but from 2006 onwards will have to adopt accounting regulations based on the State Accounting Regulation approved by the MOF. In order to do this extensive training of local government, EBF and the social security funds' officials will be necessary.

\section{A monthly public accounts bulletin is published by the General Directorate of}

Public Accounts within 3 weeks of month's end. The accounts bulletin is recorded on a cumulative basis, with the December bulletin forming the basis of the annual budget execution report. The coverage of the monthly report is confined to the existing narrow definition of central government and does not include detailed information on EBFs, social security institutions, revolving funds or foundations. The General Directorate of Public Accounts does not publish details of budget execution of local government. There is no separate formal in-year report produced for the Legislature.

\footnotetext{
${ }^{45}$ The General Government Accounting Regulation, which is the framework regulation for all general government entities classified in charts I-IV of the PMFCL, is currently being reviewed by the Prime Minister's office. For units outside the central government sector similar accounting regulations will be prepared, subject to MOF approval. For local governments, a standard accounting regulation based on the State Accounting Regulation is being developed by the Ministry of the Interior, in consultation with (and subject to approval by) the MOF.

${ }^{46}$ In particular, the transactions of the extra-budgetary funds, revolving funds and regulatory agencies were recorded on a net basis, as indicated earlier.
} 


\section{In terms of reporting, some, but not all, of the current weaknesses of the system} will be addressed in the next Budget. The Turkish Constitution mandates that draft final accounts of budget should be submitted to the National Assembly within seven months of the end of the fiscal year and that the Court of Accounts shall submit its certification within seventy five days of their submission. ${ }^{47}$ The PFMCL provides that the accounts will be submitted by the end of June with a copy to the Court of Accounts. This system works in practice. ${ }^{48}$ Reporting of final accounts is currently on an adjusted cash basis, although the PFMCL allows for the MOF to determine the accounting principles to be adopted in preparation of the final accounts. ${ }^{49}$ Parliamentary scrutiny of the budget process will continue to be limited as long as the budget coverage remains affected by off-budget activities and the complexity of the budget structure. ${ }^{50}$ The PFMCL requires the reporting of central government accounts on a monthly basis, and general government accounts on a quarterly basis. This would constitute an improvement over existing practices, where there is no consolidated reporting on general government and where information on financial operations of local governments is based on surveys conducted by the SPO and published with a 6month lag; ${ }^{51}$ final data, published by the Statistical Office three years later, are not comprehensive. $^{52}$ Implementation of the provisions of the PFMCL should also help to improve the reporting of activities that are currently outside the Budget. Article 13 stipulates that all budget revenues and expenditures shall be shown on a gross basis. One notable omission to fiscal reports relates to in-kind military expenditure and borrowing. Public enterprises are also excluded from public reports, although individual reports for internal purposes are prepared. The Treasury separately reports information on state enterprises as a sector, but this information is aggregated, and not consolidated (there are many crosstransactions not netted out). The information is typically available quarterly, with a 45-75 day lag. Final annual results are available with a 5-6 month lag.

\footnotetext{
${ }^{47}$ Article 164 of the Turkish Constitution.

${ }^{48}$ The final accounts are presented to Parliament in the form of a Final Account Draft Law which is considered by Parliament together with the Draft Government Budget Bill which contains details of the budget for the following year. Both the previous year's accounts and the following year's appropriations are approved by Parliament at the same time.

${ }^{49}$ The say2000i web-based automation system is capable of recording transactions on a cash or accrual basis although the coverage of the system is limited to the general and annexed budget government agencies at present.

${ }^{50}$ The PFMCL also provides for a number of documents to be provided with the budget including a mediumterm fiscal strategy, annual economic report, schedule of revenues foregone due to tax exemptions, debt management report, details of previous two years budget outturns and two year forward estimates, budget of central government agencies and a list of institutions deemed outside the scope of general government. These documents are expected to be included with the 2006 budget.

${ }^{51}$ Once the accounting policies outlined in footnote 40 are approved and in place it is intended that all general government entities will report quarterly to the General Directorate of Public Accounts in the MOF, to fulfill the general government reporting requirement in the PFMCL. The current expectation is that reporting of general government will commence in fiscal year 2007. Whether capacity to do so is in place, particularly in the smaller municipalities, is open to question.

${ }^{52}$ Information on local governments' enterprises, which are growing in number and size, is scarce.
} 


\section{Results-oriented budgeting and reporting}

44. The current budget documentation contains little discussion on expected outputs or outcomes from government activities, but there are plans to move towards a performance based system. To date, the budget formulation process has focused on inputs. Reporting of budget outturns is mainly on compliance rather than achievement of government objectives and priorities. The PFMCL aims to address this by requiring spending agencies to develop strategic plans which will be used as the basis for establishing a performance-based budgeting system focusing on the outputs and outcomes needed to achieve the government objectives. Eight pilot agencies have been selected to develop strategic plans. Thus far, four agencies have delivered first drafts of their strategic plans.

\section{Public Availability of Information}

\section{The coverage and quality of budget documents}

45. Coverage in the budget documents of central government fiscal activities has strict limitations, but the provisions of the PFMCL will greatly increase the coverage. At present, budget documents exclude EBF, social security institutions, regulatory boards, revolving funds, and ministerial foundations. Article 18 of the PFMCL stipulates that the draft Budget bill would be accompanied by: the Budget memorandum, including the medium term fiscal strategy; the annual economic report; a list of tax exemptions and their cost; the public debt management report; the last two years budget realizations and next two year forecast for general government; budget estimates of local administrations and social security institutions; the budget of regulatory boards and other similar bodies; and a list of public administrations not within the scope of central government but financed by it. The documents include information on defense spending, but exclude military borrowing from foreign sources for goods received in-kind.

\section{Past and forecast fiscal data in the budget}

46. The disclosure of fiscal aggregates prior to and beyond the budget year would improve under the new PFMCL. At present, only the current year is presented as supporting documentation with the draft budget bill. Under the PFMC Law, the budget is required to present the last two years' budget realizations and next two years' revenues and expenditures estimates of public administrations within the scope of general government. The secondary regulation, defining the range and detail of data to be included in the forward estimates, is yet to be published.

\section{Budget treatment of off-budget fiscal activity}

47. The treatment of off budget activities in budget documents has improved, but remains weak. A detailed statement on government guarantees is now published in the Public Debt Report and QFAs are mostly on budget. However, while PPP schemes are comprehensively listed in the Public Debt Report, no estimate of their expected future cost is 
provided. ${ }^{53}$ Similarly, the net present value of social security is not quantified (although such information is partially available from the social security funds). The PFMCL requires information on tax expenditures although, as noted, this information remains to be generated.

\section{Publication of data on debt and financial assets}

\section{Comprehensive central government debt reports are produced by the Treasury} on a quarterly basis. The reports are normally released with a lag of three months, in accordance with the release calendar posted on the Treasury's website. The reports include an analysis of the composition of internal and external debt by currency, maturity, interest rate mix and instrument. The quarterly debt management report produced by the Treasury also analyses borrowing by international lending institution. Monthly data on external and domestic central government debt service and on domestic debt issuance activities is released by the Treasury within a month of the end of the reporting month. All information is available on the Treasury's website. The quarterly debt management report also contains comprehensive data on central government external guarantees by lender, currency, interest rate mix and borrower. ${ }^{54}$ Debt reports do provide reconciliation between data on flows and stocks. There are usually discrepancies related to exchange rate valuation effects and there can be discrepancies related to on-lending, return of securities, called guarantees, and in-kind military borrowing. The time lag between the production of stock data (by the Treasury's debt management system) and flow data (by the Treasury's accounting office) may also create discrepancies.

49. Information on government financial assets is not published. However, details of receivables are reported in the quarterly debt management report which will be attached to the budget documentation as from the 2006 budget. A monthly cash balance report is posted on the Treasury's website although, as already indicated, this report does not include the balances of spending institutions, revolving funds, EBFs and foundations that have accounts outside the CBT. The government has not produced a full balance sheet compatible with GFSM 2001, partly reflecting the absence of a statement of nonfinancial assets and liabilities.

\section{Commitment to timely publication of fiscal data}

\section{The PFMCL makes a formal commitment for more regular publication of fiscal} data but advance release data calendars have not yet been announced. Under the new PFMCL, publishing is a legal requirement: the MOF must publish data on the consolidated central government monthly, and on general government (PFMCL definition) quarterly. This is an improvement over the current situation, where no commitment is made with the exception of the (monthly) Central Government Accounts Bulletin, and coverage is less

\footnotetext{
${ }^{53}$ Although it is true that any published estimates would likely be extremely tentative given the assumptions that underlie such costings

${ }^{54}$ Article 8 of the "Law on Regulating Public Finance and Debt Management -2002 (law number 4749) forbids the granting of guarantees by the Treasury on domestic borrowings. Domestic guarantees were granted in the past but there are no outstanding domestic guarantees on the books of the Treasury.
} 
comprehensive. $^{55}$ The authorities have subscribed to the IMF's SDDS data dissemination standards.

\section{Assurances of Integrity}

\section{Integrity of data processes}

\section{The reliability of budget data has improved, but the variance between the} budgeted and actual outturn of main fiscal aggregates is not explained to the public. Initial budget data have not in the past proved a reliable indicator. Supplementary budgets have been used fairly regularly. ${ }^{56}$ The system also allowed excessive within year latitude, through special appropriations, automatic payment of personnel and social security costs, generous virements, and wide latitude to increase investment spending without parliamentary approval. As recently as 2002, an election year, recurrent primary spending overshot original targets by almost 15 percent, while investment spending exceeded original targets by almost 20 percent (despite lower-than-expected inflation). During 2003-4, the government eliminated these channels for excess spending, and primary spending was within 2-3 percent of recurrent primary targets and almost exactly on target for overall primary spending. The target for the overall public sector primary surplus has also proved a more reliable indicator over 2003-4. However, the budget contingencies have amounted to almost $2 \frac{1}{2}$ percent of expenditure in 2004-5, somewhat on the high side. Deviations from original budget or program figures are not analyzed in the budget (but are covered by press statements by the Minister), and data on original programs are not widely publicized beyond initial announcements.

$$
\text { Table 3. Turkey_Budget Projections and Realizations }
$$

(in millions of YTL)

\begin{tabular}{|c|c|c|c|c|c|c|}
\hline \multirow{2}{*}{ Budget Element } & \multicolumn{2}{|c|}{2002} & \multicolumn{2}{|c|}{2003} & \multicolumn{2}{|c|}{2004} \\
\hline & Original & Actual & Original & Actual & Original & Actual \\
\hline Recurrent primary exp. & 49,600 & 56,920 & 72,500 & 74,666 & 77,486 & 75,740 \\
\hline Capital exp. & 5,736 & 6,892 & 7,999 & 7,180 & 6,409 & 7,972 \\
\hline Interest & 42,795 & 51,874 & 65,450 & 58,609 & 66,050 & 56,488 \\
\hline \multicolumn{7}{|l|}{ Revenue: } \\
\hline Income tax & 18,996 & 19,293 & 26,115 & 25,709 & 27,990 & 29,308 \\
\hline VAT (gross) & 19,500 & 20,400 & 27,729 & 27,031 & 34,147 & 34,325 \\
\hline Excises (SCT from 2003) & 12,375 & 13,649 & 22,353 & 22,299 & 26,898 & 26,289 \\
\hline Nontax & 7,007 & 10,875 & 10,294 & 10,223 & 13,666 & 16,769 \\
\hline GDP & 280,551 & 275,032 & 354,575 & 356,681 & 419,692 & 428,932 \\
\hline
\end{tabular}

Source: Undersecretariat of Treasury and Ministry of Finance

\footnotetext{
${ }^{55} \mathrm{http}: / /$ www.muhasebat.gov.tr -Website of General Directorate of Public Accounts in the MOF http://www.treasury.gov.tr/indexe.htm - Website of the Undersecretariat of the Treasury.

${ }^{56}$ Supplementary budgets were passed in 2001, 2003, and 2004. In the latter case, the supplementary budget came two weeks after adoption of the initial budget.
} 
52. There is no statement of accounting policies included in the budget or in financial reports. ${ }^{57}$ The accounting system is ostensibly cash based although a line item is included in the accounts to act as a balance for discrepancies between approved expenditures and actual cash payments. Currently, there is no published manual of accounting polices although an internal manual exists in the General Directorate of Public Accounts in the MOF. A working group has been established to produce a comprehensive manual of accounting policies which is expected to be completed in 2006.

\section{Basic accounting procedures are generally in place, but there are discrepancies} between above the line items and below the line cash balances. This mostly occurs because budget transactions are recorded on an adjusted cash basis. ${ }^{58}$ The General Directorate of Public Accounts in the MOF records transactions as expenditure as soon as budgetary appropriations have been released and approved by MOF accountants in the spending agencies. However, as the Treasury exercises control over cash releases, the General Directorate of Public Accounts may have recorded expenditure where the payment has not yet been released from the Treasury. The discrepancy is shown as a "deferred payment" balancing item. At the end of the fiscal year, the public accounts are kept open for a one month period to allow time for deferred payments to be paid down. Another discrepancy relates to the practice of permitting advance payments to spending agencies, such as the release by the Treasury of advance payments to budget agencies that have fully used up their MOF approved allocations. ${ }^{59}$ The MOF does not record such cash advances as expenditures as they have not been approved by the MOF even though the cash has been transferred to the spending agency.

\section{Progress has been achieved in developing the financial management system.} However, arrears could still be accumulated without the knowledge of central government authorities. This is because the Treasury releases cash to the spending agencies accounts rather than the invoices of goods and services, and no controls are exercised to ensure that the spending ministries have ultimately paid their obligations. Also, commitments of central government agencies are not recorded or controlled under existing budget execution procedures. ${ }^{60}$ Four main IT systems for financial management have been developed in-house:

\footnotetext{
${ }^{57}$ These tend to be largely quantitative with no explanation of the methodology used in compiling the accounts.

${ }^{58}$ Taxes are recorded on a cash basis.

${ }^{59}$ The practice of permitting advance payments is a legacy of the high inflation era, where budget agencies frequently used up their allocated appropriations due to higher than estimated costs for delivery of goods and services. The practice serves less purpose in a period of relative price stability and could in fact be considered a weakness of fiscal discipline.

${ }^{60}$ Articles 26-28 of the PFMCL outline the requirements for entering into commitments and the possibility for carry-over of commitments to subsequent fiscal years. The say2001i system appears to have the functionality to record contractual commitments but their functionality is currently not being utilized as the spending agencies are not recording this information in the system.
} 
- $\quad$ say2000i system (Payments, Accounting and Reporting System);

- $\quad$ BYES (Budget Management Information System);

- $\quad$ VEDOP-II (Revenue Management System); and

- Debt Management System.

Although their development appears to have been satisfactory, the systems are not integrated and still do not cover some key institutions. ${ }^{61}$ In particular, there is currently no automatic linkage to between the debt management system and the say $2000 i$ system. ${ }^{62}$

\section{Independent oversight}

\section{External audit is independent of the executive branch and the TCA reports} directly to the Turkish National Assembly. ${ }^{63}$ The constitution states that central government accounts should be submitted to the Turkish National Assembly within seven months of the end of the fiscal year and that TCA should submit a notice of conformity within 75 days of that date. The President of TCA is elected by majority of the Turkish National Assembly for a period of seven years and can be re-elected upon expiration of this term. The law on the Court of Accounts (section 7) prohibits the dismissal of the President or members of TCA other than on the grounds of criminal conviction or medically certified incapacity due to health problems. Previously the removal from office had to be endorsed by majority vote of the Turkish National Assembly. This provision was annulled by the constitutional court. ${ }^{64}$ There has never been an audit of the TCA itself although Article 69 of the PFMCL provides for an audit to be conducted by an independent commission appointed by the Turkish National Assembly. Article 69 is due to become effective on January 1, 2006.

\section{Both the new draft Court of Accounts Law and the PFMCL contain some changes to the budget approval process for the TCA. Prior to the enactment of the} PFMCL, the budget of the TCA was submitted to the National Assembly to be laid before the Budget and Planning Commission (together with the budget of the National Assembly) to be subsequently introduced in the draft general budget law. A copy of the Court of Account's

\footnotetext{
${ }^{61}$ Currently fifty-four spending agencies within the General Budget sector (previously the general and annexed budget entities) are direct users of the government's say2000i financial management system. Within the other three central government sectors, only the universities are current users of the system while the others maintain their own systems for budgeting, accounting and financial reporting. There are no current plans to expand the coverage of the system to include additional entities within these three sectors. The say $2000 \mathrm{i}$ system has the capacity to produce transaction based data on accounts due for payment. Details of debt management related transactions are generated by the debt management system and then forwarded to the say $2000 \mathrm{i}$ system for inclusion in the public accounts data.

${ }^{62}$ The authorities explained that one of the main reasons why it has not been possible to link the system is due to the need for physical sign -off on the details of debt service transactions by the Treasury. There is currently no legislation in place to allow for digital signatures which would allow for electronic transfer of data between the systems.

${ }^{63}$ Law on the Court of Accounts -Law No. 32 -enacted February 211967.

${ }^{64}$ Decision Number 20-11-1996-E.1996/58,K.1996/43
} 
budget was sent to the MOF. ${ }^{65}$ Under the new PFMCL, the TCA is regarded as a Chart I organization and therefore all expenditure appropriations need to be approved as part of the central government budget formulation process. The draft Court of Accounts Law proposes to reduce the term of the President to 4 years (with the possibility of one reappointment) which could be seen as compromising the independence of the office.

\section{The TCA mandate omits important central and local government institutions} and capacity shortage prevent it from fully performing its duties although steps are being taken to include many of these institutions within the remit of the TCA. The existing omissions include certain EBFs such as the Privatization and Social Solidarity Fund, the social security institutions, and the regulatory bodies, the sum of which accounts for about 30 percent of general government spending. ${ }^{66}$ The activities of foundations are also omitted. Local governments are technically covered by TCA, but capacity to cover this level of government is not high. The new draft Court of Account law contains provisions to allow the TCA to outsource certain external audits of municipalities to private audit firms. Also, although Annex 10 of the current law of Court of Accounts (1996 Addenda to the Law) states that the auditors shall perform performance audits to establish the level of effectiveness and efficiency of the use of public funds, only eight performance audits have been conducted to date and capacity to perform such audits remains extremely limited. ${ }^{67}$ Some capacity will be freed up as the TCA abandons its pre-audit role; this function is being phased out starting with the 2006 budget.

\section{A macroeconomic model has been used since 1995 by the SPO for internal} purposes as outlined in paragraph 28. The authorities have indicated that their analysis is essentially based on this model and they take into account external forecasts and analysis.

\section{The State Institute of Statistics is given legislative assurance of independence} and the autonomy of statistical production is emphasized in Turkey. The State Institute of Statistics has its own budget, has the legal right to access the data it needs, is free to determine classification and methodology in line with international standards, and publishes data before any government access. The head of the agency is appointed for 5 years, and a council oversees it. Criteria for hiring are vigorously enforced.

\footnotetext{
${ }^{65}$ In accordance with the provisions of the General Accounting Law of 1927.

${ }^{66}$ Law No. 5018 legislates for the inclusion of the Social Security Institutions and Regulatory Bodies in the TCA remit by January 1, 2006. Draft law is also being considered to include foundations.

${ }^{67}$ A twinning project funded by the EU is currently operational in the Court of Accounts. The UK's National Audit Office is assisting with training, preparation of audit manuals and development of auditing standards. The TCA currently has 540 auditors, of whom approximately half are trained. The long-term objective is to increase professional auditor number to 900 over a 10 year horizon. Efforts to build up the performance audit capacity have been hampered by the slow progress in development of strategic plans and performance based budgeting systems in budget institutions. As this capacity is developed it is likely to be accompanied by an increase in the number of performance audits being carried out by the TCA
} 


\section{IMF STAFF COMMENTARY}

60. Addressing the transparency shortcomings identified in the 2000 ROSC fiscal transparency module has been an integral part of the ambitious program of economic and structural reforms adopted by the Turkish authorities in response to the 2000-01 crisis. These shortcomings included: an inadequate budget coverage; inadequate framework for managing contingent liabilities; fragmentation of budget responsibilities across various institutions; and the absence of a medium-term framework to guide the annual budget exercise. The ROSC update undertaken in 2002 recorded progress that was made, including: the adoption of the 2002 Law on Public Finance and Debt Management (PFDML), which creates a comprehensive and more transparent risk management framework, the closing of hundreds of "revolving funds"; and the reduction in the number of EBF. But the 2002 ROSC update also pointed to a number of pervasive weaknesses in the system, including quasifiscal activities and the absence of an appropriate fiscal management framework law, needed to underpin the implementation of further reforms.

61. Since the $\mathbf{2 0 0 2}$ update, Turkey has continued to make progress toward meeting the requirements of the fiscal transparency code. In particular, there has been a substantial overhaul of the legal framework. The adoption of the PFMCL in December 2003, which is scheduled for full implementation in 2006, was designed to provide the necessary framework for further reforms. ${ }^{68}$ Other important laws related to the main fiscal areas have also been passed, including the Law on Procurement 4734 and three laws on intergovernmental relations.

\section{The gradual implementation of the legal framework has led to important} measures that translate into increased transparency. Key areas of public financial management have been thus affected, including:

- the creation of a procurement board;

- a reduction in unrecorded QFAs and the integration of "duty losses" as transfer lines in the Budget, and the curtailing of QFAs by the CBT;

- the development of a framework for monitoring liabilities and risks, which will allow the authorities to strengthen the analysis presented in the 2006 Budget documents;

- the inclusion of a medium-term fiscal strategy in the 2006 Budget documents;

- $\quad$ the move towards adopting GFSM 2001; and

- $\quad$ the extension of the mandate of the COA to all public entities.

\footnotetext{
${ }^{68}$ Aspects of this implementation are therefore imminent: the 2006 budget is due to be presented to Parliament in October 2005, but guidelines to the spending agencies are prepared considerably in advance of this date (typically May-June).
} 
63. In spite of the progress made, however, Turkey still falls short of the requirements of the transparency code in several areas and further reforms are needed to move towards meeting best international standards. Specific areas of concern include that:

- $\quad$ the enhanced legal framework enshrines the current fragmentation of responsibilities between the SPO, the MOF and the Treasury. Generally an integrated approach coordinated by a single institution would be regarded as best practice internationally as fragmentation complicates the budget preparation process.

- $\quad$ the new framework does not fully address the off-budget channels for spending that have been a pervasive features of the fiscal system in Turkey - in particular, line ministry foundations and Iller Bank; and newer amending legislation appears to backtrack on hard-won discipline in this area, allowing for spending beyond appropriations (hence off budget) subject to MOF regularization in a subsequent budget ${ }^{69}$

- the training of officials, although ongoing, remains insufficient, especially for:

○ the formulation of medium-term performance-based budgets;

- the roll out of the new system to local governments;

$\circ \quad$ the implementation of the new chart of accounts particularly at local government level ; and,

$\circ \quad$ the adherence to new reporting requirements;

- $\quad$ similarly, the development of the internal control function in spending agencies is at a very early stage, and some confusion remains concerning the future role of the agencies currently involved in the internal control process;

- the budget documentation is still too focused on inputs, and the budget management and accounting systems, although substantially improved, are not yet configured to manage a programmatic, performance based budgeting system; and,

- the tax system — both policy and administration — is complex and subject to significant discretion.

64. More fundamentally, in pushing forward with its reform agenda Turkey needs to reduce the level of uncertainty currently characterizing the legal environment. This arises from a marked tendency to modify laws even just after they were passed, and to the inability, to date and under current legislative practice, to create laws that other laws cannot amend - and which can therefore provide a firm set of rules in a given area. Indeed:

- $\quad$ The numerous, frequent, and substantial amendments that are proposed to virtually every piece of legislation harm the credibility of fiscal management and create

\footnotetext{
${ }^{69}$ Such as Law on Amendments to Other Laws (Law No. 4964), whose diverse provisions may contain amendments incompatible with sound international practice.
} 
unpredictability and risk for economic operators. This uncertainty prevails in most areas of the current framework. The numerous amendments that are currently proposed to the PFMCL (which has 84 articles in its original form) is a striking example, as is the Procurement Law which, two years after its adoption, has already undergone several major amendments. Similar uncertainty is created by the frequency with which tax amnesties have been granted in the past (37 to date; see p. 14). While the mission reckons that some amendments would be useful to address weaknesses that exist in the original texts (as discussed above), it is concerned that some of the proposed changes can unnecessarily worry investors and make them adopt undesirable strategic behavior, such as delay tax payments in the hope of an amnesty. This problem is very important for the international perception of the fiscal and business environment in Turkey.

- $\quad$ Relatedly, the absence of hierarchy in Turkey's legal system further exacerbates these uncertainties. Some countries (e.g., France) provide constitutionally for the existence or creation of higher laws - organic budget laws, tax code, framework laws for intergovernmental relations - which establish core general rules for a given area, and prevail on their concerns over other laws. Turkey does not: all laws have equal status under the Constitution. ${ }^{70}$ But this is so in other countries too (e.g., Germany), which also have no formal hierarchy among laws, but which have adopted one in practice. This was tried in Turkey through a clause in the VAT law, stating that its provisions will not be amended through other laws. Nevertheless such an amendment was indeed created through another law, creating some exemption. This led to conflicting interpretations and a judicial ruling: the exemption stood. This "flat" legal structure has serious implications, creating considerable potential to undermine legislative achievements in a fragmented manner. Restraint as there has been has come from a practice to require that all Ministers (including Finance) approve law proposals. However, in reality the legal system has not been protected against a significant dispersion of provisions in diverse laws affecting major legislation.

\section{The set of recommendations presented below aims at supporting the Turkish authorities' commitment to a strong reform agenda that will help preserve a sustainable fiscal stance and increase confidence and transparency.}

\footnotetext{
${ }^{70}$ The Constitution, however, was amended to give a special legal status to Turkey's international treaty obligations, between the Constitution and other laws.
} 


\section{A. Measures to Improve the New Budget Legislative Framework}

66. While the mission recognizes that improvements to the new budget legislative framework would necessarily require more legal changes, it urges the authorities to pay particular attention to the need to generally limit legal, changes as these have been an important element of risk in Turkey. It is essential to slow down considerably the current pace of legal amendments and concentrate on key measures. These are required in a number of areas:

To ensure that the PFMCL has primacy in matters related to public financial management, it is necessary to prevent situations where other legislation, seemingly unrelated, can dilute the provisions of the PFMCL. The authorities should examine methods of ensuring this within the Turkish legal framework.

- One possibility could be the introduction of a procedural rule in Parliament, prohibiting consideration of any draft law that includes an amendment of the PFMCL or of a principal law in a given area. With such a rule, an inconsistent law put to a vote could be subject to a point of order (by a single member) and ruled out of order by the chair of the legislature;

- Such an approach, however, could only be agreed, and in turn be respected, with the strongest political support from the government at the highest level. The challenge Turkey faces in this area deserves such an initiative and support. Such a rule should be considered as a permanent procedure if this is legally feasible,$^{71}$ in order to reduce the possibility of a reversal by future governments.

To reduce the institutional fragmentation of public financial management, and therefore improve effectiveness as Turkey moves towards a more devolved system of performancebased budget management, the authorities could:

- $\quad$ Assign the lead coordinating role in the budget consolidation and negotiation process to a single institution. This would coincide with the shift from an annual input-based budgeting system towards a medium-term output- and outcome-based performance budgeting system An alternative, and possibly workable, strategy would be to improve the coordination between the existing players, the MOF, SPO and Treasury as Turkey moves towards a system of multi-annual budgeting. This would include formalizing a process to ensure integration of the investment and recurrent budgets over the medium term and ensuring that the medium-term impact of investment budget initiatives are fully reflected in budget documentation;

\footnotetext{
${ }^{71}$ But even if it were feasible only for the life of this parliament, such a rule would be a step in the right direction, which could begin to create a culture of legislative restraint.
} 


\section{To consolidate all central and general government institutions fully under the PFMCL:}

- $\quad$ The spending agency foundations should be abolished and their assets transferred to the agencies to which they were linked;

- Iller bank should be included as part of the activities of central government; and

- $\quad$ The status of the remaining revolving funds should be reviewed to ascertain whether they are of a commercial nature, and if identified as commercial they should be excluded from the central government classification.

\section{B. Measures to Facilitate the Implementation of the New Budget Legislative Framework}

\section{Implementation plans should be strengthened and include realistic milestones} and deadlines as well as thorough costing and identification of capacity constraints. Specific supporting measures would include:

- $\quad$ Establishing steering committees to oversee the roll out of the performance-based budgeting systems, and monitor and publish information on progress achieved. Project management teams could support the committees and facilitate the roll out across all levels of government;

- Consolidating all central government bank accounts in a TSA, in the CBT, under the control of the Treasury, and, under the existing cash accounting system, record transactions as expenditures only when cash has been released from the TSA to settle payables.

- $\quad$ Clarifying the issues relating to the implementation of the new internal control and audit systems in spending agencies, in particular those related to the future role of the board of financial inspectors. The IACB should publish details of its implementation plans;

- Instructing the Court of Account to produce a strategy paper on the development of its capacity, to move towards value-for-money and performance audit;

- Improving the coordination of revenue administration through better information sharing, including full IT links and use of the TIN by the SSIs; and consolidating the tax audit function under the tax administration; and

- $\quad$ Finalizing the establishment of internal controls within the tax administration and prioritizing the establishment of a dedicated internal audit unit reporting to the head. 


\section{Measures to Enhance the Transparency of the Tax System:}

68. While there have been notable improvements in the legal and administrative framework for tax policy and administration the system remains complex and open to considerable discretion. To address this the authorities could:

- $\quad$ Consolidate the large and dispersed set of tax exemptions into the principal tax laws (and introduce provisions or a mechanism to protect the integrity of these, analogous to those in recommendation 1 above);

- $\quad$ Strictly limit COM discretion to change tax rates within-year or outside the legislative process, and make provisions to address concerns about erosion through inflation in the case of specific taxes through transparent, automatic indexation;

- Enhance the independence of the GDR and limit the role of the Minister of Finance, in particular by eliminating his involvement in approving annual audit plans and tax settlements; and

- Introduce a mechanism for the issuance of binding advanced rulings on tax issues, which would be publicized, as should all other de facto interpretations of tax law that the RA utilizes.

\section{Other Measures}

69. The mission identified a number of measures that the authorities should take in several additional areas to increase transparency. The mission understands that some of these measures are about to be taken and that preparations have, in many cases, been completed. However, the significance of these measures dictates that they should be stressed. These include:

\section{In the broader public sector:}

- $\quad$ All netting operations with other public sector entities (mutual debt cancellations) should be brought back on budget and recorded in gross terms, and the budget should carefully explain the nature of each individual transaction; and

- $\quad$ State enterprise accounts should be published individually on the government's website. Two years of prior data and a forecast for the coming year should be available, as should a commentary on the reasons for any profits losses and a clear explanation of the policy source of any sustained losses.

\section{Budget presentation should include:}

- $\quad$ A detailed analysis of individual quasi-fiscal operations, including the policy objective they are aimed at, and how they are measured and controlled; 
- Information on the source of any sustained capital transfers to enterprises;

- An analysis of any PPPs, including on the nature of associated public guarantees and an evaluation of risks;

- A discussion of the burden posed by regulations, with an assessment of costs. Labor market regulations are of special interest, as they seem to substitute for public policy (unemployment insurance); and

- $\quad$ A strict enforcement of the rules applying to tax administration employees, in particular with respect to relations with ex-employees and the blackout period before they can represent clients to the tax administration.

Civil service pay should be simplified and made more transparent. Information should be publicly available on the overall range of compensation for civil servants and public workers in each grade, and the types of allowances and in-kind benefits available and their tax treatment.

\section{Macroeconomic analysis should be further strengthened despite ongoing gradual} development. In particular, the budget should provide for sensitivity analysis in response to a range of prospective macroeconomic developments, including movements in interest and exchange rates, deviations of growth and inflation from targets, and combined shocks. The efforts made by the authorities to develop a macroeconomic model could be given more public prominence by:

- $\quad$ explaining its key assumptions in the budget;

- $\quad$ subjecting the model to public scrutiny; and

- $\quad$ highlighting any changes in assumptions in budget updates.

\section{ReCommendations Relating to Fiscal DeCentralization}

70. One key feature of most modern states is an effective devolution of responsibilities across levels of government. While some progress has been made in this direction, further reforms are needed in the following areas:

- $\quad$ Strengthen the municipalities' own revenue base, possibly giving metropolitan municipalities the right to vary the rates of local taxes within limits. ${ }^{72}$ This reduces the dependency of municipalities on State transfers and fosters fiscal responsibility

\footnotetext{
${ }^{72}$ A thorough review of all fiscal incentives and disincentives should also be made, with the aim of strengthening the former and eliminating the latter. It could comprise the right of municipalities to levy local surcharges on the personal income tax for instance. Smaller local taxes and fees should also be eliminated.
} 
and prudence, by having a given entity face the effort of raising extra revenue to achieve additional expenditure at the margin $;^{73}$

- $\quad$ Define a phased approach to strengthen and expand local government expenditure responsibilities (while avoiding a policy of decentralization from the revenue side). The decentralization sequence should always: (i) define which responsibilities and activities will be transferred; (ii) identify the resources associated with them (including facilities and expertise); and (iii) only then transfer those resources, alongside the obligations to manage and spend;

- $\quad$ Strengthen the role of the TCA in controlling municipal budgets and policies; and Reform Iller Bank to focus on municipal investment projects and subject it to market forces.

\footnotetext{
${ }^{73}$ More generally, move towards increased linking of expenditure and revenue functions at the local level to support fiscal incentives. Fees such as parking violations should be passed on to municipalities.
} 